\author{
Voice or Silence as an Expression of Identity: \\ An Analytical Study of Anita Desai's Cry, the Peacock \\ and Atiq Rahimi's The Patience Stone \\ Lamees Mohamed M. Abdelhamid El-Gafi \\ Position: Lecturer of English Literature \\ Place of work:
}

English Department-Faculty of Al-Alsun, Minia University

\begin{abstract}
What does it mean to be a woman in a world ruled by archaic laws and traditions? How could you express yourself as a woman, through voice or through silence? The purpose of the present paper is to examine "voice" and "silence" in postcolonial literary texts. In some works written by postcolonial writers, silence connects issues of language to national character, such is the prescription given to colonial females by social gender role or racial role, and it is also the form colonial writers use to revolt against such a prescription. It is fair to say that the silence postcolonial writers used in their works is actually a sound "silence", their pens make such a sound of "silence" resound in the world of letters. Thence, "silence" is no longer "silent"; the colonial females seen in the "silence" in postcolonial texts are in fact crying revolt against mainstream society from the periphery where they subsist.

Owing to different national and cultural backgrounds, silence is manifested in different forms by different writers who use silence to express different meanings. Women, in society and in fiction of Anita Desai and Atiq Rahimi, are marginalized creatures who use "silence" and "voice" to express their marginalized status of sexual exiles.
\end{abstract}


Voice or Silence as an Expression of Identity: An Analytical Study of Anita Desai's Cry, the Peacock

\section{Voice or Silence as an Expression of Identity: An Analytical Study of Anita Desai's Cry, the Peacock and Atiq Rahimi's The Patience Stone}

Language as an expression of identity and tool of empowerment, is at the heart of a culture and of a people. With using language, people describe their surroundings and, thereby, claim ownership over the wilderness that engulfs them. In post-colonial literature, the drive towards identity centers around language. What does it mean to be a woman in a world ruled by old-fashioned laws and traditions? How could you express yourself as a woman; through voice or through silence? The purpose of the present paper is to examine "voice" and "silence" in two postcolonial literary texts. In the works by postcolonial writers, silence links the issues of language and national character, it is the prescription given to colonial females by social gender role or racial role, and it is also the form colonial writers use to rebel against such a prescription. It is fair to say that the silence postcolonial writers manifest in their works is actually a loud "silence" enough to be heard. Therefore, "silence" no longer means "silent"; the colonial females seen in the "silence" in postcolonial texts are in fact calling for rebellion against the typical society from the margin where they exist.

Due to different national and cultural backgrounds, silence is displayed in different forms by different writers, who use silence to express different meanings. The researcher choses Anita Desai and Atiq Rahimi, because they both belong to a country from the third world, India and Egypt. Both writers belong to postcolonial literature. Women, in society and in the fiction of Desai and Rahimi, are marginalized creatures who use "silence" and "voice" to express their marginal status of sexual exiles.

The search for selfhood, which is the product of the individual's awareness of his/her relationship to the world, through which one discovers him/herself, acquires a special urgency and poignancy in fiction written by postcolonial writers. Women, both in society and in fiction, are marginalized creatures, roles rather than individuals, part of the process of masculine development into selfhood, the quest rather than the reality. 
Juliet Mitchell suggests' that the novel form itself arose out of woman's search for identity 'within new social structures' The earliest novelists, she believes, were not men, but women examining the nature of femininity under patriarchy. Women's stories have almost invariably pointed to the sharp dichotomy between what a mature human being irrespective of gender - might desire, and what is prescribed for women qua women. The woman's search for selfhood must battle against the long-held belief that such a desire on the part of women is in and of itself selfish and contrary to femininity, which should aim at social acceptance rather- than freedom and selfhood (226-227).

Ruthellen Josselson says that men's identity is associated with work, agency and career, while women's identity is seen as tied to the relational aspects: love, affiliation, and family (150). Josselson adds that men's identity is egocentric, while women's is interdependent. Men are concerned with separation in defining the self and women are concerned with attachment to the human community. Individuation is more important for men and relationships are more important for women (1525). This might be true in many cases, but, of course, it is not absolute.

\section{Desai and Rahimi's}

Born in 1937, to a Bengali father and a German mother, Anita Desai comes from a highly cosmopolitan background. Very few modern Indian writers have received as much international attention and acclaim as Desai. Her novels have expanded the dimensions of the Indian literary scene by giving voice to a wide range of characters previously relegated to the margins of Indian fiction: women, children, adolescents and the elderly. Desai not only brought new characters to the forefront, but she has also fixed her penetrating eye on the inner lives of the expanding urban middle class, delving deeply into the realms of imagination and fantasy through a variety of techniques relatively new to Indian writing. Her work has proved to be an inspiration to a new generation of women writers in the 1960s and 1970s, and there have been few serious critical accounts of modern Indian fiction in which she does not figure centrally.

Most of Desai's novels show that it is easy to flow with the current of family or society which makes no demands and requires no effort. However, those who cannot flow with it, whose heart cries out the great 
Voice or Silence as an Expression of Identity: An Analytical Study of Anita Desai's Cry, the Peacock

'no', who fight the current and struggle against it, they know what the demands are, and what it costs to meet them. Her female protagonists have a perpetual quest for the meaning and value of life. She portrays their attempts to create harmony between their aspirations and the social limitations. Her female protagonists also refuse to conform to the conventional norms prevalent in society. Their refusal to compromise and surrender to family ties, with its social suffocation, inevitably results in their isolation and loneliness. Those protagonists are torn between their aspirations and their obligations, between submission and rebellion towards their society's restricted beliefs.

The lives of Desai's characters are often marked by failure, withdrawals into the self, or self-assertions which are ordinary at best. Her main characters escape confining limitations, and when liberated, they create more healthy existence. These women having no faith in conventional religion and extended family, not following any conspicuous ideal, have nothing but disaster in their lives. Eventually they meet with an unnatural death or lose their mental equilibrium - Maya in Cry, the Peacock loses her mental balance and kills her husband to get rid of her suffocating environment.

Atiq Rahimi was born in Afghanistan, but now he lives in France. Rahimi speaks French, but his native language is Dari, a dialect of Farsi spoken in Afghanistan and Pakistan. By 1979, his parents had left Kabul, his father having served jail time as a political prisoner, but Rahimi remained in the city to complete high school. During the Russian occupation, life soon became unbearable, and he, along with a group of friends that included his future wife, escaped to Pakistan. There, he was granted asylum by French authorities, and went to Paris to continue his education. The Patience Stone, which is considered a condemnation of Afghan customs and Muslim practices that oppress women, and also his memories of the Russian invasion of Afghanistan, was written in French. Writing the novel in French gives him the freedom to write honestly about the most intimate feelings of his female protagonist and not feel the need to censor his words. "There was too much self-censorship when I tried Dari," Rahimi says. The novel won French's most prestigious literary prize, the 100-year old Prix Goncourt 
and has since been translated into thirty three different languages around the world (Garcia, website).

\section{Pragmatics of silence}

Language and voice are very important in the formation of identity, but if that language/voice is absent because of censorship, silencing or lack of voice, limited liberty or repressive authorities, how are individuals going to form their identity? They are essential to construct a sense of self that will enable them to survive. Voice and silence are tightly connected to the identity formation process, they are intertwined strategic forms of communication, which signify expressing thoughts, feelings, views and features of identity.

Voice and silence are vital components of social interaction. Voice and silence might appear at first sight as conceptual opposites, since one indicates uttering, while the other one means withholding. In fact, voice and silence presuppose each other. They cannot exist without each other. One gives meaning and significance to the other in such a way that the absence of one would minimize completely the importance of the other one's presence. This re-conceptualization brings several implications into focus, the most important of which is that voice and silence should be considered as social activities, rather than a state of being/state of affairs, since they are strategic and communicative forms of interaction. Silence is not always a sign of consent. Not all of the silence is definitely satisfaction or acceptance; it is not fear or escape from censorship and trial.

Deborah Tannen entitled her paper on silence "Silence: Anything but" indicating that silence is anything but nothing: void. So, what is silence? Silence is not always the synonymous of "being silent" as in "being silent" in the following situations: about matters of religion, politics, sex, shame, surprise, and meditation, for a physical necessity, as it happens during sleep and breathing, silence sponsored by some laws or instructions and ethics as we see in public libraries or during a religious sermon, silence that is a tribute to death and accompanying sadness, condolences, funeral, and the mourning that follows, silence as an answer to the questions of age, salary, marital status, religion or doctrine -varies from one context to another and from one culture to another-, silence as a 
Voice or Silence as an Expression of Identity: An Analytical Study of Anita Desai's Cry, the Peacock

sign of ending a conversation or speech, silence which is coercive or suppressed by the people of power and influence over others, silence of ignorance or contempt, silence of a lack of self-confidence or loss, silence of fear of being wrong and being ridiculed, silence before the prosecution or get arrested, and silence that is a protest or an objection.

There are three main concepts that are tightly connected to voice and silence: power, discourse and identity. Of all three, the most important concept is identity, which "not only constitutes a way of seeing or classifying myself that distinguishes me from other people but it also simultaneously allows me to see myself as similar to a class of individuals with whom I most closely associate myself or with whom I would like to be associated" (Gioia 19).

\section{Sexual discrimination \& "silence" as presented by Anita Desai}

The imagery of silence presented by Desai, is a way to express resistance against sexual discrimination. Desai's female marginalized characters are stamped with the oriental silence peculiar to the traditional Indian women. Most of their life desires are controlled by all sorts of restrictions; religion, society and conventions, they can only silently live in isolation, an exile life neglected by most people.

Cry, the Peacock, has its unique genius and characters. The themes of alienation and silence are found in this novel. Cry, the Peacock is a stereotypically "feminine" novel, a novel of feelings rather than actions. The novel shows the psychological sufferings of Maya, a young protagonist.

Cry, the Peacock is divided into three parts, dealing with the origin, development and culmination of Maya's neurosis. By connecting Maya's neurosis to her marriage, Desai transforms the conventional story of marital disharmony into a moving study of the psyche of a woman who must die at the altar of her marriage moment by moment. The novel narrates the transformation of her fears into compulsive neurosis.

Maya in Desai's Cry, the Peacock is a lover of life. When she longs for love and involvement, what she gets from her partner is a criticism on the greatness of detachment and practicality. Maya's suffering emanates from her existential desire to experience life with all the pleasures it is capable of offering. Because of her failure to establish a 
fulfilling relationship with her husband, she inhabits a world full of dark fears and turns neurotic. The novel is a disturbing portrayal of a woman involved in a desperate struggle to experience life and love or to fly out of the cage of marriage by any means.

\section{Maya's life and suffering}

Maya was a barren woman. She had been a motherless girl, raised up by her father. When she married Gautama she felt that, she lost her father and his love forever. Regularly, she used to compare things with her father's home. Maya was pleased with the company of her father and her whole world was about him. The first shocking event she met in her life was the prophecy of the albino priest, which pushed her into a fit of fear, "Death'.... 'to one of your'. When you are married-and you shall be married young'... 'Death-an early one-by unnatural causes'... 'Four years after your marriage, so the stars prophecy" (Cry 29-31). It troubled her tender heart. Each word of the priest was very clear and was recorded well in her mind.

Only in her house, Maya had complete ecstasy. She says, "delight makes me drowsy" (Cry 35). In the palm of Maya's father, Maya was innocent enough to know, the humdrums of the outside world. Maya's detached life was another reason for her psychological disorder. Whomever she loved in her life departed from her very soon and she was alienated completely. Maya loved her father and her pet dog too. Her pet dog's death affected her inner mind. Apart from all differences, she loved her husband Gautama to the core. But Gautama became careless and never noticed the psychological imbalance of his wife. Her utmost love made her to believe the prophecy. She was more scared of her death than her departure from Gautama. She believed that the revelation of the prophecy may create a wall between them. So she hided the prophecy from Gautama, who was very much detached in life. Once when Maya was fully admiring the moon, Gautama stared to talk about a case. In a fit of frenzy Maya pushed him from upstairs. Maya was psychologically affected because of the death of Gautama. As she felt guilty, she committed suicide and underwent a pathetic psychological death. 
Voice or Silence as an Expression of Identity: An Analytical Study of Anita Desai's Cry, the Peacock

\section{Maya's loneliness and dissatisfaction}

Maya's over imagination leads to her loneliness. Gautama was completely rational, logical and isolated and he never gave time for Maya. He was always stuck to the Bhagavad Gita and insisted on his philosophy of detachment.

Their indifference is mainly due to their different attitude; Gautama was always a performer and he never conjured his thought in love and attachment. Maya loved him and she wanted to fulfill his desires; whenever Gautama became indifferent, she was shattered inwardly. After the vulgar Lal's party when she said it was horrible Gautama said, "Facts are made to be accepted-to be studied. Not to be wept over" (Cry 59). This made Maya upset and she felt that Gautama has no courtesy and was moving away from her.

Maya was not even satisfied with their sexual relationship. Sex is supposed to be a part of pleasure and an expression of love in a married life. But Gautama was not enthusiastic for it because of his exhaustion. Maya compared the cry of peacock with her cry for love. As the peacock cried 'piapia', 'lover, lover', Maya also cried for Gautama to be her partner in love. But without Gautama's help, Maya felt insecure as if, she were caught up in the net of inevitable suffering and she cried for help, but in vain. As Prabhat Kumar Pandeya rightly explains:

Maya fails to evoke any response from Gautama either because of exhaustion or boredom. The sensitive wife appears to him petulant, pampered childish and immature, unable to cope with hard facts of life. The sexual hunger gives another blow to the shattered woman. Physical intimacy, the mere warmth of flesh may alleviate her suffering ... Later this unsatisfied physical hunger finds expression in an act of delicate violence. (83)

Maya seeks to be accepted by society as a separate gender, but in the end finds it is hardly possible to achieve this goal in the Indian societal and cultural context. Taken as a statue without thought and feelings, she lives in the social margin without independent personality and identity. She is spiritually alienated, her thoughts and feelings wandering by the border of the reality. She is unable to join the real world, for it is the realm of men; being silent and having slight communication with her husband when 
living together, she has to retreat to her inner world. "Silence" in Indian culture is a value considered typical of women; therefore, Maya is restricted to her traditional part, hard to escape.

\section{Gautama and Maya}

Maya's sanity is fast disintegrating under the pressures of marital discord. She is married to Gautama, a friend of her father who is a brilliant, ambitious and serious-minded lawyer. The temperaments of Maya and Gautama, are poles apart. Maya is emotional, highly strung and sensitive. Gautama is cold, detached and sober to the extent that Maya complains, "How little he knew my suffering, or how to comfort me... . Telling me to go to sleep while he worked at his papers, he did not give another thought to me, to either the soft willing body, or the lonely waiting mind that waited near his bed".

Maya, who was deprived of the affection of the mother she lost in early childhood, longs for maternal protection. Gautama treats Maya as a child which she resents, because now she needs a husband more than a mother. At one point, both of them are walking together and when Maya talks of a flower, Gautama plucks it and hands it to her saying, "Who should deny you that?... , and smiled at me as to a winsome child." (Cry 121). Then, in a debate, Maya says, "And you will think me a tiresome child for it, for showing what you once called my 'third-rate poetess' mind" (Cry 113) Thus, she has finally realized that she is not as helpless and dependent as a child. She is as competent as a man.

Maya is genuinely interested in Kathakali dances, the ballet, etc. So she requests Gautama to take her to the south. To this he says, "if that is your only reason for wanting to go all the way to the south, I suggest you wait till a Kathakali troupe comes to give a performance in Delhi..., it will be less expensive" (Cry 43). Similarly, her pet's death shatters Maya beyond measure, and she tells Gautama, "Oh, Gautama, pets mightn't mean anything to you, and yet mean a world to me," (Cry 16). This irks him and he says, "you go chattering like a monkey. I am annoyed that I have been interrupted in my thinking" (Cry 16).

\section{Depression in Cry, the Peacock}

Maya is sophisticated and sensitive, finding no pleasure in the mundane affairs of life. Moreover she has been brought up in a way that 
Voice or Silence as an Expression of Identity: An Analytical Study of Anita Desai's Cry, the Peacock

makes it difficult for her to adjust herself to the rather unimaginative atmosphere and the unimaginative lives of her husband.

Gautama's negligence and his way of detachment disintegrated Maya into psychological depression soon. Maya replaced the aspects and actions around her and was trying to say something. Arjuna's letter and the remembrance of the prophecy were also destiny. When the summer season came, it destroyed all the beauty of nature. The heat of the sun, made the flowers, birds, insects, green leaves to disappear. As the heat repressed all the beauty, Maya too felt suppressed. The dust storm is not more violent than the storm inside Maya's heart.

From the beginning of the novel, Maya's deep despair was obvious. She loved her pet dog Toto very much. Due to poor care and also the negligence of the vet, it died. Maya was crying and waited for her husband to come back home for consolation. Gautama came late and did not show any feelings. When Maya lost Toto she felt she was alone and she wanted someone to console her. She became tense and walked here and there and whenever she crossed the veranda and saw the dead body of Toto, she became more and more miserable. Maya's husband Gautama came and gave the corpse to the welfare office. Maya ran behind the vehicle which took Toto.

The death of Toto had a great effect on Maya. Being a barren woman she developed obsessive affection to Toto. She always said that childless women do develop obsessive attachments to their pets. Maya was distressed by the death of Toto and she was more nervous to see her husband's cold reaction to the death of her pet dog. As Panigrahi and Kirpal have rightly observed:

At the root of Maya's psychic retrogression lies the disparity between their dispositions: she experiences the world through the senses while Gautama looks at it through reason and commonsense. While on the metaphysical level, the tension represents a conflict, between two contrary approaches, on the literal level it turns out to be a conflict between objective reality and the Self-nurtured illusion of Maya, Maya loses control over herself because she lives in illusion. (71) 
Maya, told her husband one day that she wanted to die, saying, "Don't you know that I never mind if I die right now? ... No one more word is necessary and all is over." This comment sounds like a thunder in the silence to her husband, so much so to the readers if they try to feel Maya's pouring emotions in disguise of silence by claiming: "no one more word is necessary". It is just by such sharp contrasts that Desai succeeding in presenting silence that is by no means silent. In Desai's novels, the imagery of death is always linked with that of silence.

\section{Maya's Total alienation}

Gautama leaves Maya emotionally and spiritually starved and insecure. Perhaps their great difference in age produced a big gap in their understanding of each other, thus four years of marriage without children or vocation leads Maya towards her insanity. The death of her pet dog, Toto, aggravates her mental condition and makes her increasingly conscious of the mysterious workings of destiny. Gautama's rational mind initially fails to suspect her mental condition, and when he realized it, it is too late to mend. He is totally indifferent and insensitive to natural beauty, smells, colours and sounds in the way so characteristic of $\mathrm{Mr}$. Ramsay in Virginia Woolf's To the Lighthouse. Maya realizes:

Already we belonged to separated worlds, and his seemed the earth that I loved so, scented with Jasmine, coloured with liquor, resounding with poetry and warmed by amiability. It was mine that was hell. Torture, guilt, dread, imprisonment these were the four walls of my private hell, one that no one could survive in long. Death was certain. (Cry 102)

It is not that Gautama and Maya had never tried to understand each other. They have made several attempts to reconcile their differences, but they were always prevented from doing so by a nameless barrier. R.S. Sharma clarified that their alienation does not just result from Gautama's incapability, but it also arises because knowledge exists for Gautama unrelated to the mystery of existence, a secondary kind of reality which is organized and planned but does not have life in it. He may quote a beautiful Urdu couplet and yet remain impervious to the feelings and emotions entering to it (32). What is real for Maya is nothing but abstract for Gautama. Maya loses interest in Gautama's facts and hard realities. 
Voice or Silence as an Expression of Identity: An Analytical Study of Anita Desai's Cry, the Peacock

She feels that even if she tries to formulate a comprehensive answer for "the truth of living", Gautama would not, perhaps could not, understand it. Thus, it becomes futile for her to try to make him understand "the truth, of living". There was no place for Maya in the world of Gautama. Neither does he understand her nor does he wish her to enter his world. Thus, his world was totally strange to Maya "on his part, understanding was scant, love was meager" (Cry 93). Maya, a childless woman and having no vocation to pursue, finds herself in utter suffocating loneliness.

Maya was alienated from Gautama and also from his family. They did not know anything about love and feelings. They used to discuss issues as the parliament, extensive trade, cases of corruption, and politics but never about love. They treated Maya as a toy and never used to discuss serious problems with her. So Maya did not find any affection with them and she failed completely to communicate with them. Though they went for shopping with Maya, it couldn't help Maya to recover fast.

Maya's complete psychological depression is clear by the end of this chapter. She became aware of the drum sound of the priest and she shouted "... stop them, tell them, tell them to stop", she slowly and silently in a soundless voice replied to the drums. She thought of keeping the matter a secret because it may cause a great danger. Maya herself realized that she was becoming insane. She silently needed someone to rescue her from this great danger. She called out, "Gautama", I said, pressing my hands to my ears. "I believe I am ill. Something has gone wrong. But in silence only I no longer dared speak aloud. It must be kept a secret. The danger of it, the terrible danger" (Cry 128).

Now, Maya has awakened her real self, and started thinking of having an independent and self-reliant life. In order to translate her thinking into reality, she has started fighting against her own timid Self as well as man's protectoral shell. The fight is tough, but it has set in. Maya very much desires to live on her own without any support of Gautama. She wonders, "Father! brother! husband! Who is my saviour, am I in need of one?" (Cry 98), Thus, she is striving to be free and self-reliant, but then the timidity and diffidence, products of years of a slavish and protected life pattern, surface, causing a huge hurdle. 
As long as Maya's thoughts and feelings flowed together in all respects with those of her man's, she had the feeling of security and togetherness. Now thinking and feeling differently, she felt alienated from him, a type of alienation which generated in her a feeling of emptiness she had to fight with all her might. As long as she mutely accepted and practiced the ages-old traditions and customs, sharing the belief that a woman cannot live her life alone, accepting to be obedient and unquestioning, looking at her husband as a definite article, permanent, she felt secure and had the feeling of togetherness. Now, as she gradually becomes conscious of the futility or emptiness of the various longpreserved notions and taboos about women, she starts to oppose and break away from them.

Anita Desai's characteristic way of creating internally turbulent protagonists finds expression by association with external surroundings. Thus, for instance, in Cry, the Peacock, Maya's feelings of isolation and longings are coupled with those of the cries of peacocks. Still, one locates a kind of sublimity in the agonized inner cry of Maya when it is likened to peacocks crying in pain, madly craving for mating. She experiences inner turmoil and anguish and almost becomes a deranged being with a wounded psyche. The title of the novel connotes unfulfilled love and desire.

Desai has explicitly explored the problem of loneliness, of utter isolation from one's fellow human beings, the lack of real communication that every human being faces all through their life. As a woman, she is acquainted with the dilemma of the modern woman who has to continue to play the role of the propagator of the human race and housewife, and also that of a human being with a vocation, seeking the full expression of her personality. Anita Desai, through her use of the stream of consciousness technique; has treated these themes equally well.

\section{Progressive disintegration in Cry, the Peacock}

Maya collapsed more and more when she saw the climatic changes. She confined herself in the world of imaginary fear, and wanted to take herself off from the realities of life. She loved everyone around her but no one saw her in the right way. No one returned her love back. There was a dust storm outside her room and she also realized it deeply. 
Voice or Silence as an Expression of Identity: An Analytical Study of Anita Desai's Cry, the Peacock

Gautama made her more shocked by asking her, who Toto was; these words were said by Gautama in a causal walk in the garden. It took much time for Maya to recover from the shock which Gautama unknowingly gave her, only pains, pains of loneliness, and pains of solitude Maya said. "But it was Gautama who found many more things to teach that heart, new, strange and painful things. He taught it pain, for there were countless nights when I had been tortured by a humiliating sense of neglect, of loneliness, of desperation that would not have existed had I not loved him so, had he not meant so much" (Cry 167).

Maya, unlike a conventional woman, fearlessly fights to assert her point of view. She has the courage to tell Gautama, "You know nothing of me and how I can love. How I want to love. How it is important to me. But you, you've never loved" (Cry 112). In another situation, Gautama wants Maya to listen to him, but then she says, 'No' and further adds, "You listen to me tonight" (Cry 113). This is the voice of her new Self. While fighting the established old system, there are occasions when both of them suffer from feelings of aloneness and alienation which is natural as they are passing through a twilight period. In the process of this crusade, we see her suffering from certain weaknesses and complexes which have been very honestly highlighted by Desai.

Maya rebels internally against Gautama for his autocratic and selfish behavior. She knows the fact, "In his [Gautama's] world, there were vast areas in which he would never permit me and he couldn't understand that I could even wish to enter them, foreign as they were to me" (Cry 104). Thus, they are physically together, but emotionally far apart. She hates it, resents it and yet prefers to live with him. She does not have the courage to leave him, to flee from the cage and live the life of her choice. She is conscious of her destiny to liberate herself from the clutches of unjust taboos and customs forced on her by the male dominance, but she is not able to shake off her fear.

\section{Detachment and suicide in Cry, the Peacock}

Gautama was always disconnected from Maya. One evening he and Maya went for a stroll upstairs. They talked a little, and then they stopped talking for a long time and when she asked him, what he was thinking about, he started to talk about a case. Maya was shocked by his 
mechanical response, even at the time of affection. When they turned, at the edge of the parapet, Maya enjoyed the light of the moon. But without knowing all these things, Gautama started to move in front of her, to say something. This was the great mistake he did and Maya felt he interrupted her by, "...coming between me and the worshipped moon... 'Gautama!' I screamed in fury, and thrust out my arms towards him, out at him into him and past him, saw him fall then, pass through an immersity of air, down to the very bottom" (Cry 173). In her quest for independence she has developed certain complexes as well. One such complex was to look at womanly instincts as a sign of dependence. The fact is that "woman" is basically a woman as well as a "person". As "woman", she definitely needs man and vice versa. But, as "person", she legitimately claims freedom and independence. However, her two identities, a woman and a person have been rolled into one, only a woman, and this has led to the confusion.

Another weakness that has crept into Maya's mind, is an overdose of suspicion and doubt. This makes her not only see certain designs or some selfish motives in man's intentions and behavior, but to see them magnified. Similarly, when Maya accuses Gautama of treating her as a tiresome child and of referring to her as third-rate poetess's mind, he vehemently denies them. But she overlooks that and asserts, "You did, and you believe it now... . Because I love you" (Cry 113), in which she means a love that he could never feel or appreciate. In her struggle for liberty and equality, she cannot wink at the fact that as blind submission is undesirable, so is unwarranted suspicion. Therefore, in order to give the reader an awareness of Maya's predicament, Desai makes use of the technique of contrast. First, there is a contrast between the world of her father a world of love, tenderness, flowers and Urdu poetry, and the world of Gautama, a world of absolute detachment and arid philosophy. Second, there is a contrast between a life of freedom and a life of loveless enchainment. Marriage in the novel appears to be the ultimate fatality for a woman in a society where everything including philosophy seems to conspire against her longing for individual freedom.

By the end of the novel, Maya is ultimately driven to schizophrenia and, out of guilt, she committed suicide, her excessive love 
Voice or Silence as an Expression of Identity: An Analytical Study of Anita Desai's Cry, the Peacock

for life drives her to murder her husband. When Nila's mother heard footsteps going up the stairs, she ran to stop Maya but it was too late; she could only watch the heavy white figure screaming while going towards the bright, frantic one on the balcony.

Maya's death was the result of repressed love. The thought of losing someone whom she loved much made her move to a fit of agitation and in that state she killed Gautama. Later losing completely the lovable one gave her no reason to live and decided to go to Gautama.

What Desai tries to depict in her writings is just this extreme form of silence versus death, used by a group of exiles to question and resist the gender-specific diaspora. Her writings themselves are a type of audible silence in the sense that silence is broken by the presentation of silence. In Desai's novels, the imagery of "silence" is always linked with that of death, which seems to be the way the heroines resist "silence" with the very silence. Her writings themselves are a type of voiced "silence" in the sense that silence is broken by the presentation of silence. With such presentations, the silent women encaged in the inner resentment, express objections and challenges at the marginal position against the typical culture.

\section{The Patience Stone: women imprisoned by war and religion}

Upon taking power in Afghanistan, the Taliban enforced a strict interpretation of Sharia law. Men were forced to grow beards and women to wear the burqa. Girls' schools were closed and women were banned from working outside home or leaving their homes without a mahram, a male family member. The Taliban's religious police meted out severe punishments for any infractions of the moral order, including public executions, amputations, and stonings. They were particularly vicious toward women and in cities, which were viewed as immoral.

After the fall of the Taliban regime in 2001, women in Afghanistan made major achievements: their right of education has improved, the numbers of women who die during pregnancy and childbirth have decreased, and women in many parts of the country are now able to participate in public life. According to Amnesty International's recent report on the position of women in post war 
Afghanistan highlights, millions of Afghan women and girls have seen progress in their lives since 2001: millions of girls are currently enrolled in schools, women can work outside their homes, while the constitution grants women and men equal rights. However, there are extensive human rights violations against women in Afghanistan. These include great number of domestic and sexual violence cases, child abuse and forced marriage and violent husbands and fathers, and little or no governmental action to stop these abuses:

Violence against women and girls persisted, and there was a reported increase in armed groups publicly punishing women including through executions and lashings. State and non-state actors continued to threaten human rights defenders and impede them from carrying out their work and journalists encountered violence and censorship. The government continued to carry out executions, often after unfair trials. (Amnesty International, 2017)

Still, Afghanistan remains one of the most difficult and dangerous places in the world for women. Women's rights in Afghanistan are rarely enforced in practice and access to basic services like education and healthcare remains extremely limited. As well as living in an international conflict zone, women are likely to face the risk of domestic abuse. Women who are active in public life are especially subjected to intimidation and the daily threat of violence. As the Afghan government and the international community begin to plan their country's future, however, many Afghan women fear that they will be abandoned and their hard earned rights sacrificed in the search for a political deal. The Patience Stone has given a voice to the many thousands of Afghan women who suffer in silence

Most portrayals of war are told from the viewpoint of men who fight in those wars. Slight attention is paid to the lives of women who have to face the worse costs of any violent conflict. Atiq Rahimi's The Patience Stone tackles this issue. Set in 1979, it draws upon his memories of the Russian invasion of Afghanistan. The Patience Stone focuses on the dilemma of an unnamed women ruled by old-fashioned laws and 
Voice or Silence as an Expression of Identity: An Analytical Study of Anita Desai's Cry, the Peacock

patriarchal traditions. The novel presents the life of a young Afghani nameless woman who fights to care for herself and her two young daughters as her husband, the ex-Jihad fighter, lies unconsciously, while the war rages just outside her door. The Patience Stone is a dreadful look at the effect this war had on the lives of the women who lived there. Although the novel is set during Afghanistan's civil war, it never shows scenes of soldiers fighting but rather focuses on the interior life of its energetic female heroine. It highlights not only the wife's struggle to survive but also her determination to carve out a new existence for herself and her daughters. The Patience Stone is a novel of sensibility rather than action. It portrays the psychological sufferings of the unnamed young protagonist.

\section{The husband as a "patience stone"}

According to a Persian mythology, there is a magical black stone capable of absorbing all the secret sufferings of those who confess to it, until the stone shatters into a million pieces and the possessor of the stone is comforted of all his/her pain. This stone is the basic allegory in The Patience Stone. The novel shows how the heroin cares for her immobile husband, who has been in a coma for more than two weeks. He has been paralyzed after taking a bullet to his neck. Sitting in silence hour after hour, the woman takes the advice of her aunt and begins a one-sided conversation with her comatose husband, who becomes his wife's "patience stone", which passively absorbs all of her sufferings and sorrows. He becomes a sounding board for her fears, angers, and fantasies. For the first time in her life, she feels he is listening to her, and she begins to reflect on her life, "You have stayed alive just to listen to me" she tells him. Slowly but surely, the reflections become confessions, when she takes on a shy, stuttering rebel soldier as a lover, she shares with her paralyzed husband all the intimate details of their sexual meetings. And we realize to what extent a woman will go to avoid neglect and rejection.

\section{The heroine's life and marriage}

Rahimi's The Patience Stone exposes the complicated inner thoughts of a woman's mind and her secret life in a world constrained by 
patriarchy and norms. The novel presents a distinctive perspective on the awkward lives of women imprisoned by merciless social customs that lasted for centuries and are mainly shaped by wrong understanding of religion and early tribal conflicts. The heroine reveals that she was married at the age of seventeen to a much older man. He was a local war hero still fighting on the front lines when their wedding took place. The two did not even meet until two years after the ceremony. She spent three years as a married virgin, forbidden from seeing her friends and family, "I had to sleep in the same room as your mother, who kept watch over me, or rather my chastity...I didn't even know how lonely I was". When he is back from war, she discovers that he is an uncaring, violent, arrogant war hero husband with whom she has to tolerate cruelly disconnected sex, and who won't let her kiss or touch him: "You were scared," she reflects with delight, "because you didn't know how to kiss a girl." Ten years later, as he lay paralyzed from his bullet wound, not the result of battle on the field, but an unplanned fight provoked by a personal insult, his wife lays bare all of her sorrows from childhood to motherhood. She tells her unconscious husband, "My aunt was right to say, those who do not know how to make love make war". Now, their roles are intensely overturned: he lies paralyzed and helpless as a child, his life is in her hands, and now she can kiss his fixed face. "I can do anything I want with you," she tells him. "I can talk to you about anything, without being interrupted or blamed!". "I have never understood why," she had thought earlier, "for you men, pride is so much linked to blood". It is therefore strongly figurative that her husband's wound, in which a bullet is stuck, does not for her surprise - bleed at all, and apparently significant that while "Sange Saboor" is a Persian word for Stone of Patience, in French, sang means blood.

While she has no illusions he will be fulfilled by what she shares, the heroine is hopeful of her own eventual fulfillment. If he regains his ability to move, "he'll either be the same animal or he'll change," she tells her aunt. To him, she says: "You'll love me the way I want, because you'll know all my secrets."

\section{Fight against silence}


Voice or Silence as an Expression of Identity: An Analytical Study of Anita Desai's Cry, the Peacock

In the beginning of The Patience Stone, the wife has been abandoned by her husband's relatives who have fled the fighting, leaving her to care for her sick husband and their two young daughters. Not only is he abandoned by his companions of the Jihad, but also by his brothers. She struggles to find food for her family as well as the medication needed to keep her husband alive and also begins to battle with the silence this isolation has imposed upon her.

Her isolation is broken only by irregular visits from the local imam. He gives the young woman spiritual advice but little in the way of concrete help. Every trip she is forced to make outside her garden door, in order to buy food and medication, is fraught with danger. She also desperately searches for an aunt who is her only surviving relative and does this while trying to somehow avoid the conflict which rages constantly in the streets surrounding her home. Each day the fighting moves a little closer and threatens to surround her and her family.

At one point, the young woman is forced to abandon her husband and hide with her children in a neighbor's cellar to avoid the heavy shelling. They emerge to find the house has been robbed by passing fighters who have taken all the remaining food, leaving her comatose husband unharmed.

The woman searched a lot for her missing aunt. When she eventually finds her, she discovers that she is working as a prostitute in order to survive. However, and after her neighbors are slaughtered, she sends her children to stay with her aunt. She decides to stay behind, to care for her husband and try to protect him from the violence which is now on their doorstep. In fact, it is her aunt who explains the Persian myth of the patience stone, a rock used through the ages as an object for confessions for the suffering.

Hiding her husband in a curtained-off niche, the woman is alone when a group of religious fighters bursts in. She tells them she's a prostitute, knowing they won't rape an unclean whore. She also knows they may steal back later individually — because they think she's an unclean whore. Yet the reappearance of one young soldier awakens 
something like tenderness in her. Or perhaps it's an unexpected sense of sexual power. Or maybe it's just revenge.

When she meets that young soldier, she feels a new sense of identity and purpose in her life. To relieve her boredom, the young woman begins to talk to her silent spouse and tell him all the secrets of her life, this long monologue forms the basis of the novel. Ironically, the conflict has presented the woman with an unexpected opportunity to speak openly for the first time to a husband she hardly knows. A husband who we later learn has mostly brutalized his wife during their 10 -year marriage. Now though for the first time she has the opportunity to make her voice heard.

Erik Erikson discusses such cases of inner conflicts, "we are spiritual beings having a human experience which makes us a dual being: spiritual and physical". Inner conflict occurs when the physical self battles the spiritual self. Theses selves can be referred to as the false self and the real self. The inner voices we hear arise from these two selves are the positive voice from the real self, and the negative voice from the false self. The false self is composed of many parts and voices which is why we experience self-talk such as "part of me wants to this and part of me wants to do that". The false self is also the source of our character defects (113-121).

She talks about her childhood, her suffering, her frustrations, her loneliness, her dreams, and her desires. She says things she could never have done before, even though they have been married for the past ten years. Therefore, this paralyzed man unconsciously becomes her patience stone. She reveals a series of increasingly shocking revelations to her him; she exposes a list of injustices committed against Afghan women by patriarchal authorities. She even recounts the time her father lost a great deal of money in a quail contest and was unable to pay his debt. His resolution sacrificed her older sister, and marked her rather violent coming-of-age. Those fighting quails kept by the woman's father are insistently presented as symbols of both male genitalia and pointless male violence. 
Voice or Silence as an Expression of Identity: An Analytical Study of Anita Desai's Cry, the Peacock

It is clear that everyone has his own needs, which is for other people may interpret as signs of losing senses or being an eccentric person, but for the person himself they are basic and essential. According to Erich Fromm, the needs of attachment and security are seen and analyzed as "psychic needs":

Man's existential conflict produces certain psychic needs common to all men. He is forced to overcome the horror of separateness, of powerlessness, and of lostness, and find new forms of relating himself to the world to enable him to feel at home. I have called these psychic needs existential because they are rooted in the very conditions of human existence. They are shared by all men, and their fulfillment is as necessary for man's remaining sane as the fulfillment of organic drives is necessary for his remaining alive. (304)

Therefore, the woman frees herself of innumerable constraints through the simple yet revolutionary act of speaking aloud, especially about her sexuality. The unnamed wife becomes inspired by the "talk cure" experience, despite the fact that war rages on outside their home and many of her family members are killed. The Patience Stone suggests that the unnamed woman's realization of her desire for tenderness in her sexual relationship with her husband is the first real step toward her liberation.

She resents her husband for having sacrificed her to the war. Yet she cares, and she speaks to him. While in the streets, rival factions clash and soldiers are looting and killing around her, she speaks of her life, never knowing if her husband really hears. And it is an extraordinary confession, without restraint, about sex and love and her anger against a man who never understood her, who mistreated her, who never showed her any respect or kindness. ("Why am I telling you all of this?" "Why am I talking so much?")

As the fascinating narrative continues, and as more taboo-busting outbursts and events accumulate - including her casual selling to the handsome young soldier - she gets increasingly carried away with her unrestrained confessions, until she unveils the most shocking, most 
dangerous and, for her husband, most ruinously weakening secret of them all.

The novel's uncompromising exploration of the effects on a young woman's self-esteem and sexuality of living in a society preoccupied with the control and repression of her gender is unpredictable, intriguing and ultimately even a little shocking.

\section{Conclusion}

After the analysis of "silence" and "voice" showed in the above two novels, it is clear that the two writers put forward silence and voice as a question to guide their readers to reconsider language from the angles of racial discrimination and sexism. "Silence" is manifested in the two novels in different messages due to the different national and cultural background, however, to sum it up, the silence displayed in their works includes merely the following states: one is the compelled silence, and the other one silence is itself a language, a heard silence. When "silence" is employed as a resistant language, that obliged "silence" is broken.

Sometimes, silence is more to be feared than the anxiety of voices. In silence, sometimes we are sure something vital to our future is communicated to us, but we cannot hear what it is. The spirits can adopt a tongue that we cannot comprehend.

In speech, we use silence as a buffer between words, a gathering of thoughts, or a rebuke to the words of another. This silence is sometimes awkward, sometimes calming, and sometimes pregnant with foreboding menace, quiet triumph, or insubordination and deceit. In writing, silence exists between the words, lines, and chapters and in the reader's subconscious. No matter its form, silence carries with it a power capable of oppressing masses, uniting peoples, and hiding the inner workings of the mind. Devout monks have used silence as a way to achieve divinity and rulers have used silence on their constituents as a mode of political oppression for centuries. In this way, silence exists as a flexible political, personal, and global force. Silence in its sacral form allows the purveyor to achieve a state of unsurpassed tranquility. However, more often than not, silence is used as a weapon by oppressors to quiet the "other" in society. Silence encourages the oppressor, not the oppressed. 
Voice or Silence as an Expression of Identity: An Analytical Study of Anita Desai's Cry, the Peacock

Desai uses the "silence" imagery, which is manifested more as the resistance against sexism. "Silence", a marginal status of sexual exiles, is often complimented as a traditional virtue of Oriental females, but is questioned in Desai's writings. "Silence" in postcolonial literary texts connects the issues of language and national character, while in the works by female postcolonial writers, it is the prescription given to colonial females by social gender role or racial role, and it is also the form colonial females use to revolt against such a prescription. It is fair to say that the silence female postcolonial writers manifest in their works is actually a sound "silence", in the world of letters. Thus, "silence" is no longer voiceless; the colonial females seen in "silence" in postcolonial texts are in fact crying revolt against mainstream society from the periphery where they subsist.

In The Patience Stone, The wife is a mess with her two little girls playing obliviously in the next room, she begs her husband to wake from his coma and take charge of her life once more. His brothers have fled; her prayers to Allah go unanswered. Bombs shake the house by night; by day, men with guns prowl the streets, hoping to kill in the name of Allah. Her only way to survive was to break the silence. Although, The Patience Stone is set during Afghanistan's civil war, it never shows scenes of soldiers fighting but rather focuses on the interior life of its spirited female heroine. It highlights not only her struggle to survive but also her determination to carve out a new existence for herself and her daughters.

The author did not only give a voice to the poor Afghani woman, he also gave a voice to all Afghani women, and he gave voice to Afghanistan history. In the novels whose history, gleaned from firstperson narratives, primary documents, etc. that have often failed to be incorporated into "official documentation," emphasize that in some cases, because of this lack of official historical documentation, fiction is the only voice of history.

Both women are hypersensitive and highly individualistic. They do not voice their protest against uncongenial surroundings and insensitive people. Maya refused to yield and compromise and prefer death to a miserable life, while the unnamed protagonist prefers to speak up and express her anger even for a paralyzed husband. In their existential 
struggle they suffer intensely but refuse to be crushed. The refusal to be crushed, the attempt to fight and voice protest, is the core of two novels.

The need to withdraw to preserve their sanity and quest for identity, it is as important as the need to be involved in useful social activities. By exploring the mind of two characters, the two writers do not only examine them from a psychological point of view, but they attempt to reveal to the reader the social situations which push their characters into such positions. They try to examine the role of society, represented in in the authority of the family - represented as a husband - which produces disintegrated characters.

My purpose of illustrating the stand taken by Maya and the unnamed protagonist is to create an awareness in women that now the time has come to break the silence, to free the bird of its cage. It is time for women to realize their own identity and to proclaim their freedom with definite clarity. In the two novels, the two female characters exhibit a lack of unquestionable and self-validating certainties. They are deprived of a secure sense of personal identity and so are incapable of confronting the hazards of life, social, ethical, spiritual and biological. They suffer from what is called in psychology 'ontological insecurity', [ontology is the metaphysical study of the nature of being and existence]. Ontological insecurity occurs when a person cannot feel his/her real existence in the world, in contrast, to an ontologically secure person who has a sense of his/her existence in the world as a real, live and whole person. This feeling disables them from realizing their potential and from achieving full human status that gives a person a sense of consistency and cohesiveness. With struggle or inner conflict, they may succeed in emerging out of the prison of the Self into the larger, saner existence. 
Voice or Silence as an Expression of Identity: An Analytical Study of Anita Desai's Cry, the Peacock

\section{Works Cited}

Amnesty International Report. Retrieved from https://www.amnesty.org/en/countries/asiaandthepacific/afghanistan/report-afghanistan.2017

Desai, Anita. Cry, the Peacock. New Delhi: Orient Paperbacks, 1986.

Erikson, E. H., "The Problem of Ego Identity," Journal of the American Psychoanalytic Association, Vol. 4, pp. 56-121. 1956

Fromm E. The Anatomy of Human Destructiveness. New York: Holt, Rinehart \& Winston, 1973.

Garcia, Maria. "Beneath the veil: Atiq Rahimi's 'Patience Stone' charts an Afghan woman's awakening". Retrieved from http://www.filmjournal.com/content/ beneath-veil-atiq-rahimispatience-stone-charts-afghan-womans-awakening. 2013

Gioia, Dennis A. "From Individual to Organizational Identity". Whetten, David A. and Godfrey, Paul C. (editors). Identity in Organizations: Building Theory through Conversations. SAGE Publications inc. Thousand Oaks, pp. 17-32. 1998

Henderson, Lesley \& Watson Noelle. Contemporary Novelists: Contemporary Writers of the English Language. Chicago and London: St. James Press, 1991. Print.

Josselson, Ruthellen. Finding Herself: Pathways to Identity Development in Women. San Francisco: Jessey-Bass Publishers, 1987. 
Mitchell, Juliet. "Femininity, Narrative and Psychoanalysis". Ed. David Lodge Modern Criticism and Theory; A Reader London: Longman, 1991.426- 430.

Pandeya, Prabhat Kumar. "The Lonely Voyage: Feminine Psyche in Cry, the Peacock". Indian Women Novelists. Ed. R. K. Dhawan. (Vol. 3, pp. 79-93). New Delhi: Prestige Books, 1991. Print.

Panigrahi, Bipin B. \& Viney Kirpal "The Individual and the Search for Self-Identity in Cry, the Peacock". Indian Women Novelists. Ed. R.K.Dhawan (Vol. 3). New Delhi: Prestige Books, 1991. Print.

Rahimi, Atiq. The Patience Stone: Sang-e saboor. (P. McLean, Trans.). New York: Other Press. (2008).

Sharma, R. S. Anita Desai. New Delhi: Arnold-Heinmann. (1981).

Tannen, Deborah. "Silence: Anything but". In: Tannen, D., SavilleTroike, M. (Eds.). Perspectives on Silence. Ablex, Norwood, NJ, pp. 93-111, 1985. 